\title{
Situated rationalities and management control change - an empirical note on key actors, situated rationalities and generalised practices
}

\author{
Julie Bertz
}

Dublin City University Business School, Dublin, Ireland, and

Martin Quinn

Queen's Management School, Queen's University Belfast, Belfast, UK

\begin{abstract}
Purpose - This paper aims to offer an incremental contribution, augmenting the notion of situated rationality as proposed by terBogt and Scapens (2019). Through insights from empirical data, the authors explore the role of situated rationalities of key individual actors in processes of management control change.

Design/methodology/approach - A qualitative research approach was adopted with qualitative data collected in a single public service organisation through face-to-face interviews, organisation documentation and observations.

Findings - The findings present the important role of key individual actors in bringing about a new situated rationality in a housing department. External austerity forces combined with actors' experience rationalities acted as a stimulus to change existing management control practices in the management of public services.

Originality/value - The paper conceptualises "experience" rationality, capturing the experiences of a key actor, including elements of leadership style. Drawing on a story of a complex process of management control change, this paper thus reveals interactions between generalised practices and situated rationalities which were not highlighted by the extended framework of terBogt and Scapens.
\end{abstract}

Keywords Budgets, Balanced Scorecard, Public service, Embedded agency, Situated rationality, Management control change

Paper type Case study

\section{Introduction}

Burns and Scapens (2000, p. 3) wrote "whether management accounting has not changed, has changed, or should change have all been discussed". From their work, they offered a conceptual framework, which presented insights on management accounting change and/or stability. The framework uses an institutional lens, drawing on the notions of rules and routines, and how they interact over time across the realms of actions and institutions to

(C) Julie Bertz and Martin Quinn. Published by Emerald Publishing Limited. This article is published under the Creative Commons Attribution (CC BY 4.0) licence. Anyone may reproduce, distribute, translate and create derivative works of this article (for both commercial and non-commercial purposes), subject to full attribution to the original publication and authors. The full terms of this licence may be seen at http://creativecommons.org/licences/by/4.0/legalcode

Received 4 March 2021 Revised 15 September 2021 27 October 2021 
QRAM 19,1

interpret management accounting change. Their work has been cited approximately 2,000 times, and several authors have offered developments and suggestions to Burns and Scapens (Dillard et al., 2004; Quinn and Hiebl, 2018; Bertz and Quinn, 2014; van der Steen, 2011) and combined it with other theoretical approaches (Nor-Aziah and Scapens, 2007) to explain the often-complex nature of management accounting change.

More recently, terBogt and Scapens (2019) offered a framework updating and adapting the original Burns and Scapens framework. terBogt and Scapens (2019) thus offered an incremental contribution, offering additional utility for researchers (Corley and Gioia, 2011). One of the additions put forward by terBogt and Scapens (2019, p. 1803), is the notion of situated rationality, "which is the form of rationality situated social actors adopt in a specific situation - i.e. how they think about and rationalise what they should do when faced with that situation". In this paper, we continue in this vein. This paper explores the notion of situated rationality in a complex story of management control reform in a local government setting. During the empirical stages of this research, while situated rationality was apparent, our observations revealed some potential issues with terBogt and Scapens' (2019) framework and situated rationality. The actions of key individuals in a leadership role in the processes of change were of particular relevance in the case data (see later), suggesting the rationalities of key individuals are not fully captured in the framework of terBogt and Scapens (2019). Thus, a motivation of this paper is to offer an incremental contribution, augmenting the notion of situated rationality as proposed by terBogt and Scapens (2019) through insights from empirical data. More specifically, we address the question, what is the role of situated rationalities of key individual actors in processes of management control change?

The remainder of this paper is structured as follows. The next section describes, relatively briefly, the original Burns and Scapens framework, the extended framework offered by terBogt and Scapens (2019) and provides brief insights from some leadership literature. Then, we describe our case study research approach, followed by our findings. The latter sections of our findings discuss the empirical data relative to terBogt and Scapens (2019) extended framework, pointing to the situated rationality element of their framework. Aspects of the role and leadership style of key actors are highlighted. We then conclude the paper and thoughts for future research are outlined.

\section{The original and extended Burns and Scapens frameworks}

\subsection{Original burns and Scapens framework}

Before describing the extended Burns and Scapens framework, it is worthwhile summarising the original framework. The original Burns and Scapens framework (Figure 1) is well-known. In short, it encapsulates four main concepts - institutions, actions, rules and routines - to describe the processes of management accounting change and explain stability. Scapens (1994) is a useful starting point to understand Burns and Scapens. Scapens (1994), in a theoretical paper, posited management accounting as routinised. He noted, "accounting practices are routines which involve doing things [and] if accounting is institutionalised it is through such routines that behaviours are predictable and understandable despite organisational complexity and uncertainty" (1994, p. 314-315). In contrast to Burns and Scapens, Scapens (1994) focused on describing institutions and routines but did refer to the processes of institutionalisation and offered a "sketched out" (1994, p. 316) framework in non-visual format. Later, Burns and Scapens developed the 1994 work to derive a visual depiction of management accounting practices as routinised, and potentially institutionalised.

Burns and Scapens outline a process by which management accounting practices may evolve, change, stabilise and re-evolve over time. As shown in Figure 1, on the left side, they labelled steps in this process, namely, encoding (A), enacting (B) and reproduction (C) of 
rules and routines, which may result in institutionalisation (D). An assumption of Burns and Scapens is that management accounting change (or stability) can be explained using institutional phenomena such as rules and routines, which Burns and Scapens (2000, p. 6) defined as "the way things should be done" and "the way things are done" (2000, p. 5), respectively. Burns and Scapens (2000, p. 8) also highlighted the link between the realms of institutions "the taken-for-granted assumptions which inform and shape the actions of individual actors" and actions. These two realms capture the "on-going cumulative process of change through time" (2000, p. 9).

The process of change per Burns and Scapens (2000, p.10) begins with the encoding of "institutional principles into rules and routines", influenced by existing rules and routines embedded in existing institutionalised practices. These existing institutional norms are enacted by actors (line B) and over time, repeated (changed) behaviour (lines B and C), may become institutionalised (line D). Thus, over time, management accounting practices can become taken-for-granted (institutionalised) and stable. Also, over time, new institutions may evolve, which are interpreted in terms of existing rules and routines (line D and the continuum of institutions shown in Figure 1). Thus, there is a potential for change to management accounting practices from within an organisation and change would typically be slower, longer term and evolutionary. While Burns and Scapens is thus more focused on intra-organisational change, they do acknowledge revolutionary change may occur as "a result of major external change, e.g. take-over, economic recession, market collapse, and so on" (2000, p. 13). In such cases, (re-)actions are "likely to be determined largely by the current context of the organisation, including its routines and institutions" (2000, p. 13). Although, as Burns et al. (2003) suggest existing institutions can and should be challenged, and on occasion, change will demand a "breaking the bubble" of the organisation's taken-forgranted assumptions.

While terBogt and Scapens (2019) is the focal development of Burns and Scapens in this paper, a brief mention of other conceptual developments of Burns and Scapens is useful. The nature of rules and routines as proposed by Burns and Scapens has received some particular
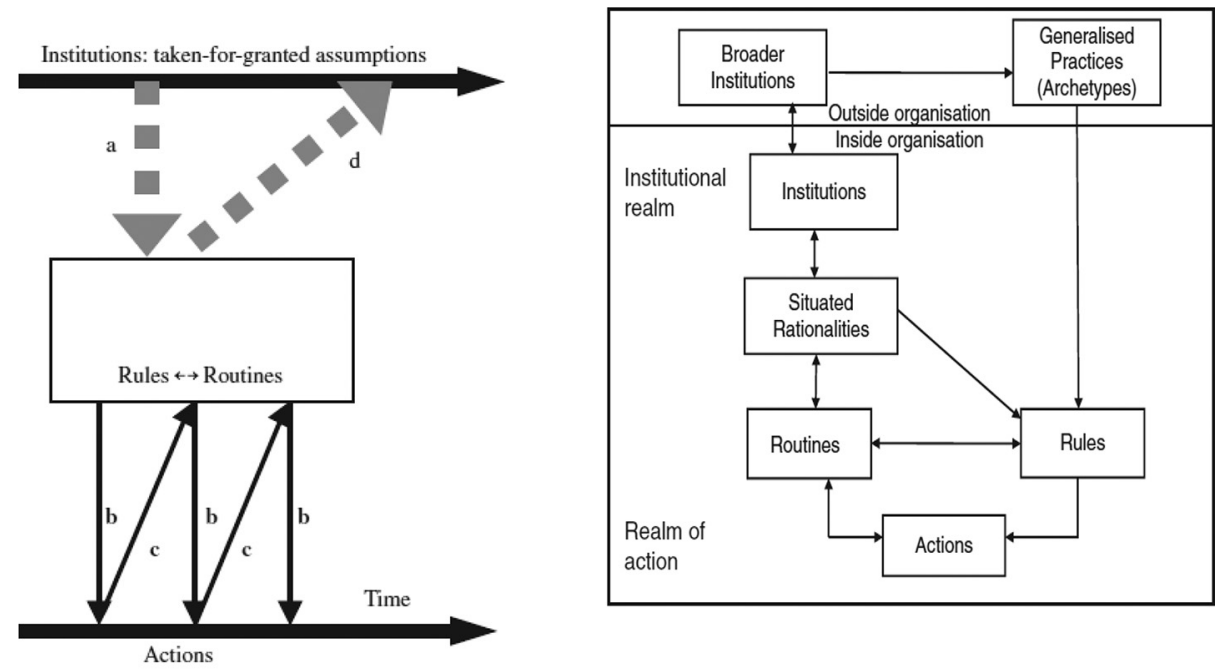

Source: Burns and Scapens (2000, p. 9), terBogt and Scapens (2019, p. 1810)

Figure 1.

Original Burns and Scapens framework (left) and extended framework (right) 
QRAM 19,1 attention. On routines, work by authors such as Lukka (2007), Siti-Nabiha and Scapens (2005), van der Steen (2011) and Quinn (2011) has explored routines in a management accounting context in some detail. Quinn (2011), drawing from organisational literature suggest routines as ostensive (the generalised idea of the routine) or performative (the actual acted routine), suggested rules should be considered as written and that routines may preexist rules. Quinn (2014) offered historical data supporting the notion that routines are present before rules and noted how routines display remarkable stability. Quinn and Hiebl (2018), explored the potential origins of routines, something Burns and Scapens did not explore in detail. Quinn and Hiebl (2018) support the path dependent nature of routines put forward by Burns and Scapens, while also reflecting on factors which may influence the path taken. On the nature of rules as per Burns and Scapens, Bertz and Quinn (2014) extended the Burns and Scapens conception of rules, introducing formal and informal rules. Oliveira and Quinn (2015) similarly offered some insights on rules, considering a rule as a cognitive structure. Oliveira and Quinn (2015) also include technologically embedded rules, e.g. rule embedded within accounting information systems. Literature such as that mentioned here does not "add" new concepts to Burns and Scapens, rather extends those presented in the original Burns and Scapens. We now turn to the work of terBogt and Scapens (2019), which does introduce some new concepts.

\subsection{Extended Burns and Scapens framework - new concepts}

The extended Burns and Scapens framework offered by terBogt and Scapens (2019) - see Figure 1, right - includes some new concepts and process flows. terBogt and Scapens (2019, p. 1802) offer these extensions in response to critiques of the original Burns and Scapens such as "its failure to explicitly recognise the impact of broader (field level) institutions [and] issues of agency, power and the role of trust". The extended framework retains the core concepts of rules, routines, action and institutions. Like the original Burns and Scapens framework, the extended framework also depicts a process of change, but to incorporate critiques such as those mentioned, institutions have been separated into those within and without the organisation and the concept of situated rationalities has been introduced - and is explored in the next section. Here a brief outline of the process of change per the extended Burns and Scapens is worthy of mention. First, terBogt and Scapens (2019) suggest that in any situation there are institutions within and beyond organisations, which together shape situated forms of rationality in an organisation. They note that these two forms of institutions both have the potential to shape behaviours. In turn, institutions and situated rationalities affect routines as shown by "double-headed arrows between institutions, situated rationalities and routines" (terBogt and Scapens, 2019, p. 1810). Second, they include generalised practices in the extended framework. These stem from "broader institutions [and] will shape wider forms of rationality, which are embedded in the institutional logics, and also 'generalised' forms of practice which extend beyond the boundaries of the organisation" (terBogt and Scapens, 2019, p. 1810). These generalised practices are thus shown as outside the organisation. terBogt and Scapens (2019) suggest that such practices are more likely to influence organisational rules. Third, they remark that specific individuals and/or groups in an organisation may have the power to impose rules and draw on their situated rationality when imposing rules. They state "consequently, for these powerful individuals and/or groups there could be a direct link between situated rationality(ies) and the rules they impose" (terBogt and Scapens, 2019, p. 1811). As illustrated in Figure 1, the linkages between rules, routines and action are similar to the original Burns and Scapens. However, it should be noted that terBogt and Scapens (2019) are more specific about linkages in their framework. Double-headed arrows are specifically used 
to highlight recursive linkages. Thus, for example, a recursive linkage from broader institutions to actions is clearly shown on the left-hand side of the extended framework.

\subsection{Extended Burns and Scapens framework - situated rationality}

As mentioned earlier, situated rationalities is the focus of this study. Drawing on references to organisational, institutional and accounting literature, terBogt and Scapens (2019) map out a recognition in this literature that management accounting practices (or other organisational practices) are situated (Ahrens and Chapman, 2007; Englund and Gerdin, 2008; Englund et al., 2020; Jørgensen and Messner, 2010; Thornton et al., 2012). Drawing from this body of literature, terBogt and Scapens (2019) offer several points on situated rationalities as reflected in Table 1 . While not intended as extensive, we have added our own comments to Table 1 to operationalise the concept of situated rationality for this study. We can glean from Table 1 that the notion of situated rationalities captures both structure and individual agency, as terBogt and Scapens (2019) clearly mention individual actors. Thus, although they may not state it, their framework (arguably more clearly than Burns and Scapens) captures the possibility of embedded agency being a source of management accounting change, i.e. it is more focused on individual actors than Burns and Scapens. Embedded agency is a paradox that agents who are embedded in and conditioned by social structures (such as institutions) can change these same structures (Battilana et al., 2009; Hiebl, 2018; Garud et al., 2007). Indeed, actors experiencing embedded agency have been termed institutional entrepreneurs (Battilana and D'Aunno, 2009) and extant literature has identified sources of embedded agency. For example, Englund and Gerdin (2018) suggest six generic sources of embedded agency, which are mainly structural in nature - Generality, Inadequacy, Ambiguity, Multiplicity, Embeddedness and Reflexivity (GIAMER). Arguably, Englund and Gerdin (2018) under-represent the role of individual actors and their personal characteristics and experience as a source of embedded agency in their GIAMER sources. In

\begin{abstract}
terBogt and Scapens (2019)
"the essential nature of what we term situated rationality; i.e. the particular forms of rationality which are applied by individuals or groups of individuals in specific situations" (p. 1809)

"Incorporating the notion of situated rationality in the Burns and Scapens framework will enable us to focus on the situated nature of management accounting practices, while simultaneously recognising the constraining influences of institutions within the organisation and the agency of the individual actors therein” (p. 0.1809)
\end{abstract}

"situated rationalities comprise both the rationalities embedded in the broader institutions, as well as the rationalities embedded in the local institutions. It is this multiplicity of institutions which shapes the situated rationalities within the organisation” (p. 1810-11)
Our comment

Situated rationalities are relevant to individual and group actions

Situated rationalities of management accounting practices may be affected by institutions and the agency of the individual (structure and agency)

Situated rationalities of management accounting practices may be affected by external and internal institutions

"specific individuals and/or groups within the organisation, who have power Recognises that individuals, to impose rules on the other members of the organisation, may draw on their with power, may influence situated rationality when imposing such rules. Consequently, for these powerful individuals and/or groups there could be a direct link between situated rationality(ies) and the rules they impose on others" (p. 1811) rules by drawing on their situated rationality
Table 1. terBogt and Scapens (2019) on situated rationalities 
QRAM 19,1

other literature, actors' individual characteristics such as education (Baños Sánchez-Matamoros et al., 2014), prior work experience (Boxenbaum and Battilana, 2005) or political party identification and political values (McMullen et al., 2016) have been suggested as sources of embedded agency. In line with this notion, Battilana et al. (2009, p. 78) noted "individual characteristics such as demographic and psychological factors" as potential sources of embedded agency. While terBogt and Scapens (2019) do not exclude embedded agency (Table 1), as our empirical data will show, the agency of individual actors seems to suggest that their situated rationalities [1] may be quite diverse from the situated rationalities of the organisation itself similar to the idea of contradictions (Seo and Creed, 2002), which is acknowledged by terBogt and Scapens (2019). However, Seo and Creed (2002) have been criticised for not giving enough attention to the individual level of analysis - for example, Battilana (2006) argues that human agency can also be activated in the absence of a contradiction. Arguably, terBogt and Scapens (2019) similarly may not have given enough attention to individual actors. As stated earlier, terBogt and Scapens (2019) is a framework to be built on, and we do not question its fundamentals. However, the empirical data described in Section 4 provides some insights into the role of individual actors and boosts the utility of the extended Burns and Scapens framework. Also revealed in Section 4, is how the leadership of a new Chief Executive (CE) (with a different situated rationality) influenced and shaped management control reforms in the case organisation. Therefore, it is also useful to briefly consider some aspects of the leadership literature despite situated rationality remaining the key focus of this paper.

\subsection{Leadership}

Literature suggests that organisational performance is affected by leadership (Agle et al., 2006). Leadership is complex and no one leadership approach fits all scenarios. According to Sturm et al. (2021, p. 1), "leadership is a social process depending on the characteristics of the leader, followers, and the interaction between the two - it is also contextually rooted, within a broader social milieu". According to Leavy (2021, p. 22), there is a paucity of research on "the dynamics of the relationship between the leader and led", with some research stating that not all 'followers' are the same (Bastardoz and Van Vugt, 2019; Matthews et al., 2021). Tentatively, this draws a link to the notion of situated rationality, in that 'followers' may experience situated rationalities differently. It also suggests a tentative link to the skills of a leader in a particular situation, i.e. a situated rationality. Much literature is devoted to effective leadership skills. For example, effective leadership skills are often cited as vision, collective activity and context (McDermott, et al., 2010; Darling, et al., 2012). Schoemaker et al. (2013) argued that research has presented these skills independently and never in unison. Therefore, they outlined six skills required by leaders to lead strategically and manage effectively in uncertain times, namely, "anticipate, challenge, interpret, decide, align and learn" (2013, p. 2). They argued these skills are apparent in adaptive strategic leaders, that is, "someone who is both resolute and flexible, persistent in the face of setbacks but also able to react strategically to environmental shifts" (2013, p. 2). More recently and focusing specifically on CE leadership skills, Bryant and Sharer (2021) outlined seven tests of a good CE:

(1) Can you develop a simple plan for your strategy?

(2) Can you make the culture real - and matter?

(3) Can you build teams that are true teams?

(4) Can you lead transformation?

(5) Can you really listen?

(6) Can you handle a crisis? 
(7) Can you master the inner game of leadership?

These tests closely echo the strategic leadership skills identified by Schoemaker et al. (2013).

From the above brief description, it is clear the leadership literature offers much comment on leadership skills. In the case of the CE in our case data (Section 5), such skills were apparent. As shown in Table 1, individuals with power (i.e. leaders) may influence rules by drawing on their situated rationality. Thus, leadership skills are considered briefly within our discussions, although as stated, the focus of this paper is on the notion of situated rationality.

\section{Research approach}

As outlined in the introduction, this research aims to extend and develop our understanding of situated rationality, as proposed by the framework of terBogt and Scapens (2019) by exploring how a new $\mathrm{CE}$ made management control reform decisions in a particular situation. This aim was addressed through a detailed qualitative case study using three data collection methods: in-depth interviews, documentary data and observation.

\subsection{Data collection}

The primary data collection method adopted was semi-structured interviews, as they allowed follow up questions for clarification when responses were ambiguous or unclear. Furthermore, this interview approach was combined with "creative interviewing", which allowed flexibility to respond to situational dynamics (Mason and Dale, 2011, p. 36). The same researcher was present at all interviews and interviewees were encouraged to speak freely and openly "about what they felt was most affecting them and their job" (Yazdifar, 2013, p. 120). Interviews were conducted in an Irish local authority, hereafter named Irish Authority [2] during a time of austerity with a specific focus on the housing department. The delivery of affordable housing is a contentious issue in Ireland making its focus an interesting area of study. The main purpose of the housing department was/is to facilitate the provision of suitable and cost-effective housing accommodation and support. One of its key remits includes the provision of housing support through a combination of rented housing from its own stock and/or to provide financial assistance to renters of private accommodation. Other services include improvement works to existing housing, provisions of sites for private housing projects, provision of accommodation to the travelling community and extending existing houses to meet tenant needs. In recent years, there has been a major reorientation in social housing policy with a greater emphasis on sourcing social housing units provided from the private sector as opposed to Irish Authority constructed new homes. The annual budget of the housing department is presently more than $€ 100 \mathrm{~m}$.

In total, 20 semi-structured interviews ranging in duration from 60 to 120 minutes were conducted up to 2013 and contact was maintained until 2019. Executive managers (i.e. Chief Executive, Chief Financial Officer, Directors of Services), senior and middle managers of operations and accountants (senior and middle levels) were selected for interview given their roles in the day-to-day management of public services. The questions asked were based on literature covering new public management reforms, situated rationality, leadership and management accounting/control change. Initially, a general interview guide approach was adopted with several open-ended questions on service delivery and management control practices (i.e. Describe your role in the organisation. Why (and when) do you think this local authority decided to restructure its service delivery? How was the housing service restructured? How was reform communicated? Were budgets and performance review plans followed prior to reform?). During initial interviews, it became evident that change was ongoing and attributed to the appointment of a new $\mathrm{CE}$ and austerity measures. Additional 
QRAM 19,1

questions were subsequently asked when new issues materialised or when initial responses needed further exploration (i.e. Who initiated and designed new reports? Who communicated their use? Was it implemented and put into practice after development?). All interviews were pre-arranged and all interviewees were given an outline of potential questions (Bryman and Bell, 2015). From the outset, the researchers clearly explained the purpose of the interviews and stressed confidentiality. Interviewees came from different organisational levels, and to maintain their anonymity, they were all referred to as 'he'. Furthermore, all interview quotes were attributed to equivalent titles rather than their actual role title - namely, chief executive (CE), senior managers and managers. All interviews were recorded digitally and transcribed. Analysis of the data was an ongoing process throughout the data collection period. This assisted in unravelling the interrelated change activities and revealed certain management control reforms within the housing department, due to the situated rationality of its $\mathrm{CE}$.

The organisational documentation analysed included minutes of management meetings, housing strategy plans and budgets along with media articles, for example, government reports and annual reports. In addition to these documents, prior to interviews and also while analysing company documentation, the interviewer sat in open office spaces and observed staff interactions in an unobtrusive manner (Webb et al., 1966).

\subsection{Data analysis}

Data analysis was undertaken in an ongoing iterative fashion (Eisenhardt, 1989) starting with interviews. Notes were taken during each interview, and they also detailed observations on the body language of each interviewee and their reactions to questions posed. In the days following the interviews, the recordings were transcribed. The recordings were then listened to and checked to the transcriptions to ensure reliability and to understand pauses and unspoken words (Yazdifar, 2013). Interviewees also provided internal documentation which provided support and some additional detail on comments made by interviewees.

In terms of analysing the interview transcripts, a manual coding approach was used. For the coding process we followed a typical qualitative data analysis approach, from understanding the empirical data through to drawing conclusions (Miles and Huberman, 1994; Saunders et al., 2015). Given the research objective of this paper - to ascertain what is the role of situated rationalities of key individual actors in management control change - we analysed transcripts to tease out answers to questions such as what did people say, why did they say it, what did they think and why, and so what does this mean for the research objective? With such questions in mind, themes and patterns were found providing clues as to the nature of the situated rationalities of the organisation, its key actors and the situated rationalities of these actors. With these clues to hand, potential relationships to the existing terBogt and Scapens (2019) framework were posited and explored to determine if they were similar (or not) to the empirical observations. A key focus at this point of the analysis was to determine any role that actors' own situated rationalities played alongside or in addition to those of the organisation. This allowed us to draw the conclusions presented in this paper.

\section{Findings}

We now present our findings and illuminate how a new CE brought a different form of situated rationality to his role. The first three sections describe the general processes of change in and around Irish Authority's housing department, including its existing situated rationalities. The latter two sections relate the organisational changes and situated 
rationalities to specific management control techniques, namely, budgeting and a balanced scorecard.

\subsection{Chief Executive's background and reform role}

The CE had the power and determination to mobilise change and amongst other things, attributed this to resource power from his position of authority and the realisation of staff that, due to the world-wide financial crisis (post-2008), the existing service-delivery and management practices were no longer viable. In the CE's words:

Everybody realised that things had changed after September 2008, so I didn't have to really convince people. And, a cohort of people realised that this can't go on. So, I wasn't really coming in and changing what people were necessarily happy with, and comfortable with, or going to defend. They realised that something had to change.

Thus, many staff soon saw the $\mathrm{CE}$ as a change agent who "possessed the authority, conviction and persuasion to impose the changes" (Burns and Baldvinsdottir, 2005, p. 739). He arrived at Irish Authority with substantial experience having worked in the local authority sector, in several organisations across Ireland. Senior Manager remarked:

The $\mathrm{CE}$ has a finance background and is big into analysing the numbers. And, he is looking for a lot more stuff than the previous CE might have done.

The CE explained how he immediately began to see opportunities for change after questioning certain existing metrics:

I found it very hard to grasp the organisation as a whole. I struggled to understand the budget presented to me during my first year of tenure.

The CE's past experiences did not accept the taken-for-granted ways of managing housing and his confusion about the information presented to him convinced him of a need for reform. Accordingly, one of the first things he did was request details on how housing was resourced and managed:

Early on [the CE] questioned the staffing and other costs needed to deliver housing. What were the processes involved, and how efficient are we in terms of current operations? (Senior Manager).

The CE was co-opting senior management and staff buy-in to Irish Authority's policy and decision-making which would help to begin change, or put another way, to create a new form of situated rationality in which senior management supported housing service reform. Having three independent geographic units (i.e. I, II, III) managing and delivering housing was no longer viable. A senior manager illuminated how new individuals to the organisation held different forms of rationality compared to those within Irish Authority when he stated how, when he first started working at Irish Authority:

Having three units, in my opinion, meant it was a nightmare to manage the housing service. It was more or less like dealing with three separate authorities. I was an outsider coming in. It seemed to me the most natural thing to have housing delivered by one head of service to the city/ county, and that this unit concept was inefficient.

Furthermore, each housing unit interpreted the housing legislation differently and had slightly different ways of delivering their housing services, illustrating how different situated rationalities and routines were in operation at each of the three units:

Our architects in I always applied for Part 8 planning [3] when they were drawing up plans for extensions to houses for persons with disabilities. After reviewing this process and the planning 
QRAM 19,1

legislation I told them "we don't need to get Part 8, it is not a new house and it is not over 126 sq. $\mathrm{ft}$ which requires it". But, the architects' reply was "we have always done it". It transpired that unit III also followed the same routine as unit I, but unit II did not apply for Part 8 planning. After my questioning, it meant that I and III no longer had to routinely apply for planning permission, so a big chunk of time was saved. I was delighted (Senior Manager).

Such differences in each unit's approach to housing-delivery and management control only became highlighted when the new $\mathrm{CE}$ and a newly appointed director of housing questioned it. The identification of the inconsistency between the planning legislation (external rule) and architects' practice (routine) helped shape staff "consciousness and action to change the present order" (Seo and Creed, 2002, p. 225). Consequently, for example, the accepted way of applying for planning permission for extensions to houses for persons with disabilities was abandoned when the new director of housing - who had the situated rationality of "judging" housing management practices - used his power to instruct architects that this was no longer a requirement. Through his continuous questioning, the CE was subtly and gradually eroding the existing situated rationalities in the housing department at Irish Authority. Senior management's willingness to listen made them conscious of the inefficiencies in their management control practices. The CE had brought Irish Authority's problems (contradictions) out into the open. Thus, in the very initial stages of the processes of change, the $\mathrm{CE}$ involved senior managers and directors in the reform process.

\subsection{Changing the housing department structure}

As hinted at above, an insufficiency of housing-related information, incited the CE to request the Development Directorate (DD) [4] to carry out a strategic service review (SSR) on housing. In the context of an economic crisis, the aim of the SSR was "to develop the most economic, efficient and effective management structures” (Source: Internal document, 2009). A senior manager acknowledged the enormity of this task for DD:

It must have been a very difficult job for the DD, in particular because they had to look at all the activities in housing. In other words, they had to carry out an 'x-ray' of all the service activities, see what staff were tied into these activities, and think about how we could better deliver and manage the services within housing. What staff would you need in each unit to serve the public and keep the politicians happy.

The SSR findings disclosed that staff generally did not have clearly defined job roles. Rather, their roles were multi-functional which effectively meant that the same person could be responsible for a variety of tasks. The director of housing's time was consumed by routine, operational matters that should have been handled by middle management, thereby, allowing the former to focus on more strategic issues. Worse still, tasks and activities, which were probably more appropriate for junior grades were being handled by senior staff - e.g. payments, administration work, recoupments and more. There were also some cases where junior staff were handling tasks that were more appropriate to middle-management or even senior staff. One Senior Manager was mindful enough to question "how can we manage this and how do we ensure efficiency and performance, when someone is pulled and dragged across a broad range of activities?". Furthermore, a lot of the housing service-delivery information developed over time was in people's heads, and not formalised in any way. That is, a situated rationality existed, but was different in each unit and not shared across the three housing units. This is reflective of what terBogt and Scapens (2019) refer to as how agents deliberate on the most appropriate routines to use in a particular situation, i.e. a situated rationality for each housing unit, not necessarily shared across the three units. 
Upon completion of the housing SSR, it was decided the existing structures in housing were to be changed. This challenged the situated rationality of the present actors as management were seen to have determined the housing structure without subordinates' input. Any staff input was more of a strategic move to be seen to have included staff comments; however, the decision had already been made to restructure housing:

The new structure was imposed on staff whether they thought it was good, bad or indifferent and to be fair, staff were consulted to a certain degree but it was going to be done anyway (Manager).

As a result of the SSR, Irish Authority established five housing business units, which would report into an overall decision-maker, the director of housing (Figure 2). One senior manager described the restructuring as "something which is fairly radical for a local authority".

Together, the five housing business units (Figure 2) were accountable to one individual, the director of housing. Having housing services under the remit of one director ensured housing issues were dealt with as efficiently as possible. The five to one (i.e. five business unit heads to one director) reporting structure implied control was much tighter than previous, and staff could be held accountable due to their clearer responsibilities. It ensured a two-way communication across the new flatter service structure.

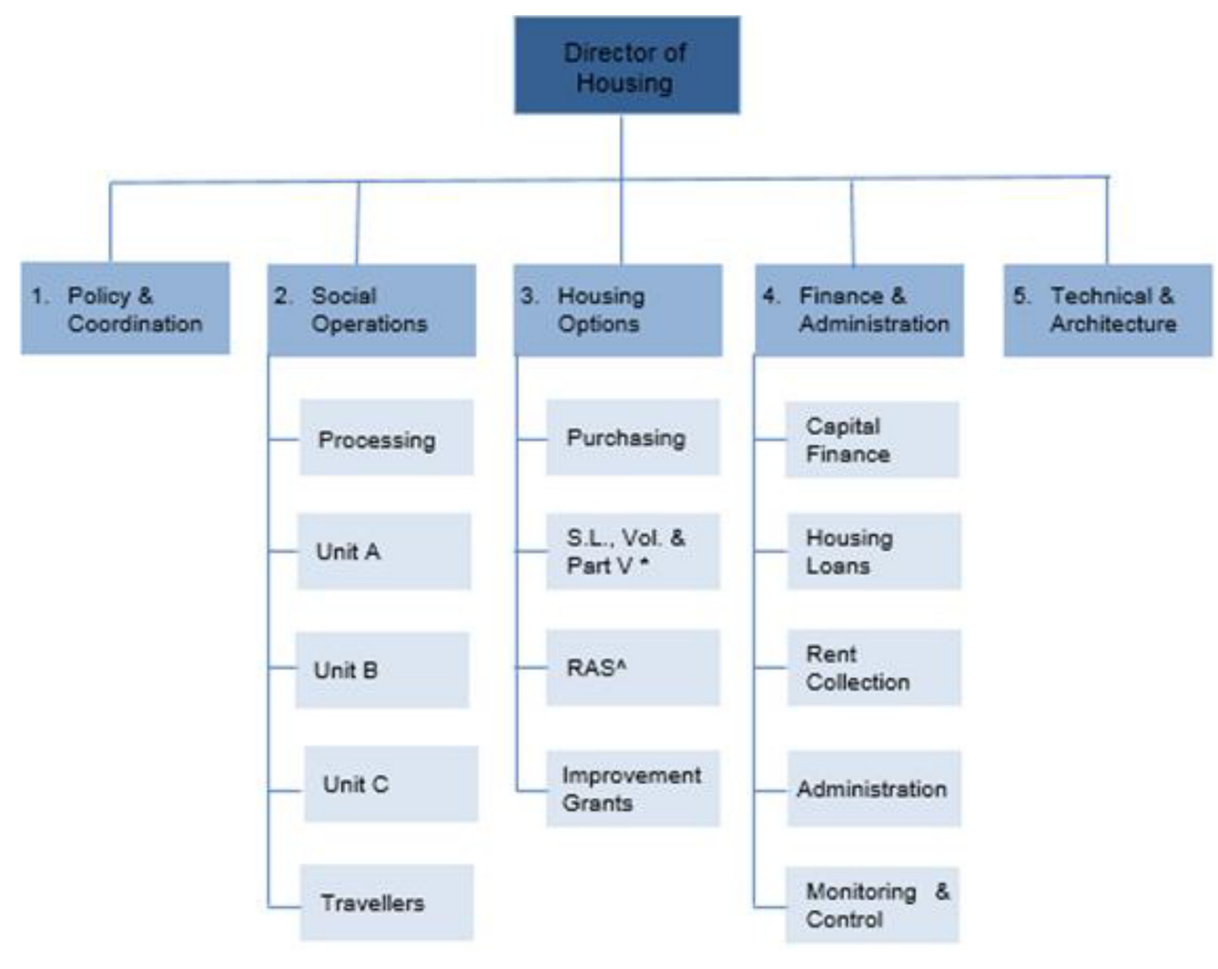

* Social Leasing, Voluntary and Part V
^ Rental Accomodation Scheme

Figure 2.

Irish Authority's new centralised housing structure 
QRAM 19,1

If one service unit is getting frustrated by the fact that another service unit is not delivering their part of the service fast enough, the unit heads can try and hammer out the issue between themselves and if it's the case that they cannot sort the issue among themselves then there is one decision maker who can intervene and make the call. So control is now much tighter. The structure is now very clear (Senior Manager).

The structural changes depicted in Figure 2 also meant staff jobs were redefined and new rules established clearly outlining what their job roles entailed. This, in turn, nurtured increased staff accountability as is evident in the following comment:

Staff were now held more answerable to tasks. They could no longer simply pass tasks on to their senior managers. Management staff were being made manage. With this type of arrangement, if there is a grade six in charge of the business unit, and they are reporting directly to the director of service, they will have to perform. There is no other option. There is nobody else they can go to (Senior Manager).

The $\mathrm{CE}$ was very proactive and vocal in pressing his intention for managers to manage. In doing so, he brought an explicit focus on increasing hands-on management which would turn around staff performance, that in turn, would bring about improvements in organisational efficiency. The $\mathrm{CE}$ was essentially creating a new situated rationality. The next section describes the implementation of the new housing structure, illuminating the activities of the $\mathrm{CE}$ and his allies in handling the reforms.

\subsection{Changing rationalities in the housing department}

To achieve the new centralised housing structure depicted in Figure 2, some situated rationalities required changing. First, the $\mathrm{CE}$ had to decide which unit, I, II, or III would be designated head of housing. The CE knew, politically, he would have to deliberate this allocation carefully to also keep councillors (i.e. elected local representatives) on board with the new plans. Knowing this, the strategic decision was made that the directorship for housing would be located at III while other local authority services such as roads and water were later allocated to I and II. This presented the idea that services were fairly allocated between the three geographic units. The decision as to which unit got which service was determined by where the newly appointed directors of service were currently located and for the $\mathrm{CE}$ to push the restructuring through, he deliberately:

[The $\mathrm{CE}$ ] handpicked the three directors, for housing, water and roads. He needed to select three people who believed in the process, who believed in the change and who were solid with the workers. The CE could not have put someone into the role who thought this whole thing was a mess, no consultation, no this, no that (Senior Manager).

The CE gained the support of his potential allies by presenting the structure in terms of values and problems that resonated with their situated rationality (i.e. deliberation based on the agent's department/function). He also promoted and communicated the housing SSR report as superior to the existing housing structure. The first newly appointed director of housing was asked personally by the CE to stand in, for one year only, to ensure the implementation of the new housing structure happened. The reason for a one-year tenure was that housing already had an incumbent director. Interviewees were puzzled by the appointment, because the incumbent had years of housing experience but in hindsight, they could see why this new person was selected - he "worked days and nights" (Burns, 2000, p. 575) and was a keen advocate of performance management and risk control, as highlighted in the quote below, with another senior manager stating "the (new) director was mad into performance management and risk". 
He was brought in for the year to set up the new housing structure. The year has now gone, and he is still here. To be fair, he did a super job. He had no major background in housing. To be fair, he managed it, worked so hard on it, working days, nights, weekends and all. The CE hand-picked him. And you know, I suppose at the time, people would have questioned that was a bit of a strange thing, because there were directors who had experience in housing, but when you stand back from it a year later you could understand how he was picked and put in there (Senior Manager).

These comments highlight how the new director was an ally of the $\mathrm{CE}$ as he shared the same Management control change "settled ways of thinking" for housing's reform and had the determination to drive it as explained by the $\mathrm{CE}$ :

At least mentally, he was committed to making the new housing structure happen, rather than another director who might say, well, that's all very fine, but that won't work around here. So that helped. He was the best person to head it up on the basis he had all the thought processes needed. His management report reflects it [5].

A second challenge to the successful restructuring of housing was the existing situated rationality of job roles. For example, some housing staff members were upset when they learned that their job role in housing located at unit II was being relocated to unit I. So, despite having maintained their location at unit II they were now going to be allocated a new job role. According to interviewees, housing is a service where staff members were emotionally attached to their jobs. They feel their job role purpose is to provide good quality housing for people in need as described by one senior manager:

There are some people who have a personal attachment to the job. Like the Head of III said at one of our meetings, he said, "you really do have to have a heart to work in housing. I see staff who are very attached to particular aspects of their job. You have staff dealing with rent applications for elderly people and people with disabilities and you have staff that see very sad situations here. It is hard to explain to people why anybody would want to hold on to that job role, but some staff do". And, in this day and age, when the public sector is being run down to such a huge extent, some staff need to feel that they're doing something that confers meaning for them.

This is similar to the comments of Shamir (1991, p. 440) who argued "the motivation for carrying out tasks and continuing in an employment are not only a matter of instrumental or even 'hedonistic' motives (such as pleasure from the activity itself), but the motivation may come from the meaning for the individual, e.g. in terms of affirmation of his or her identity and collective affiliations". Nevertheless, despite some evidence of staff upset at their changing job roles, this was overcome by concerns in the Irish economy. A senior manager explained:

Staff were also aware that people were losing their jobs right left and centre outside of the local authority and our wages and pensions had been cut so that is why people accepted it, they don't like it but they got on with it.

Third, the existing situated rationality of housing management, as explained by the CE, was another potential difficulty to reform:

Housing by its nature is about people and people in lots of difficulty. And housing staff are very good at thinking about housing and social problems and all that mix of what they're trying to fix. However, they don't necessarily spend a lot of their time thinking about the management structures and the reporting and the project management and the KPI's. So it's a pretty challenging directorate for anybody to kind of say, well, we really are about fixing all of these problems with people who need housing but we also need to sustain the view that you still need to have financial management. 
QRAM 19,1

To overcome this contradiction, the CE noted:

You have to have perseverance and it takes a long time. I've used the management team, I have probably lost sight a small bit of it now, but each director of service is required to come with a management report every quarter to our management meeting. So even if they don't agree with this new management accountability ethos or they're milk and watery about it, they know they have to present a management report on their service activities at the meeting.

This new "generalised practice of judgemental performance" (ter Bogt and Scapens, 2019, p. 1816) - the quarterly management reporting to present the financial performance of their services to the $\mathrm{CE}$ and their colleagues - was radical for the senior managers. As the CE put it:

This creates competition among the directors because nobody wants their figures to be low in front of their colleagues. It gets them to question why certain figures are poor etc. It is a slow process, but they know it will be asked for and they have to present their quarter results.

Thus, we can see the $\mathrm{CE}$ acknowledges that change can be slow, but by requesting management control information on a consistent basis, staff behaviours began to change. They also began to interact more favourably with management control information, and we now turn to what this information was.

\subsection{Management control techniques change - budgeting in housing}

Budgetary control, while existing, was not an enforced practice at Irish Authority but this changed because of the newly implemented housing structure and changing situated rationalities in housing described in Sections 4.2 and 4.3. A reflection of the nature of the old budgetary control approach is captured in a comment from a senior manager, who described how when he arrived at Irish Authority:

I couldn't get over it when I arrived here first. Nobody in my business unit knew about budgets.

[You] would have been massively overspent and still nobody took people to task on it.

With the new housing structure, the manager of the Finance and Administration business unit (Figure 2) controlled capital and revenue expenditure budgets.

We're monitoring the budget, we control both the expenditure and income side to see if they have exceeded $50 \%$ of the budget, if half the year is gone, we are asking questions of the code holders, who are responsible for the codes as to why you have exceeded the budget, or if they are not up to the $50 \%$ as to why isn't the money being spent. It is monitoring and controlling budgets to an extent that was never there before (Manager).

Thus, housing staff were being held accountable for their spending and income figures. Thus, the generalised practices of what would normally be expected in a typical budgeting scenario were in place and were - for the first time - formally recognised as the way in which "things should be done" (Burns and Scapens, 2000, p. 6). For example, to open a new budget code or use an existing budget code the requesting person had to get approval from their senior manager - a typical generalised budgeting practice, as exemplified by the following quote:

If somebody opens a budget code and they don't have funding towards it, then the senior manager will be asked at the end of the year "why did you open that code when there isn't any budget for it. Where are you going to get the money for it. There is now stricter guidance for people to follow (Senior Manager). 
Historically, the central finance department of Irish Authority had control to open budget codes, but that task was taken away from them and allocated specifically to the senior manager of the Housing Finance and Administration business unit. A senior manager explained how necessary it was for him to continually re-enforce to staff that their historic routine of opening budget codes was no longer acceptable. He had to keep repeating this guidance as per the quote above (new rule) until the practice became routine and eventually over time the norm to no longer open budget codes without his approval. Again, this shift in responsibility is an example of a typical generalised practice - in this case devolving budgetary control to the responsible manager, as captured in the following comment:

Finance cannot open a budget code in housing because the senior manager is responsible for the housing codes, not them. Whereas before, you see, it would have been them. He has to keep drilling it into them and saying "how many times do I have to tell you, you can no longer open a budget code". I think that is the only way, by drilling it into them and I think they are getting there now. We have more control now (Senior Manager).

Thus, housing staff were now held responsible for their allocated budgets and this shaped their views because what gets "accounted for" represents what is important (Burchell et al., 1980, p. 5). Thus, Irish Authority's situated rationality regarding budgeting was changing. Budgets were no longer prepared to legitimise spending (the historic situated rationality) but used to plan and control housing's spending and income activities (the new situated rationality).

\subsection{Management control techniques change-balanced scorecard in housing}

As part of the processes of change, a balanced scorecard (BSC) was also implemented as a new management control tool by the newly appointed director of housing - referred to locally as the department's business plan. The business plan was prepared manually as part of the housing department's new management control system. According to one senior manager:

Business planning is back on the agenda again, the $\mathrm{CE}$ has it on his agenda, he mentions performance management a lot now and I think he is seeing it coming through now in housing so it is diffusing.

Historically, there were three housing plans [6] prepared in units I, II and III. Now the housing department has a centralised business plan under the responsibility of one individual, i.e. the director of housing. Thus, the performance management information available now for housing was different.

Now we have a centralised business plan and we've one person responsible. For example, if you go back to the unsold affordable housing at I had no problem, they had eight houses. B had five hundred houses and A had about two hundred houses. And, each unit is trundling along in its own way and trying to get the houses let or sold. Being centralised means they are all in one place, it is all amalgamated, it is a lot clearer to move them all along together. So, it is different in that sense. It is easier to control, you should achieve your targets more easily, because they are within the control of one body, not three different geographical units. That's the change there really (Senior Manager).

The housing business plan (i.e. BSC) allowed the managers to communicate strategically to staff as it provided the "context for organisational actions, the meaning of events, knowledge, information and motivation” (Mazzei, 2014, p. 91). However, the actual term BSC was not used, as the director of housing believed that the housing staff would just view it as another irrelevant management tool. Thus, the director recognised the importance of the 
QRAM 19,1

Figure 3.

Irish Authority's

Housing

Department's business plan (BSC) existing situated rationality when implementing reform in terms of a generalised management control practice (i.e. the BSC). In the words of terBogt and Scapens (2019, p. 1818) "the form of rationality underpinning the new performance measures could be accommodated within the existing situated rationality".

The director of housing implemented the BSC in the housing department. Now the director would not use that lingo out there, because that lingo is the worst thing you could use. The director referred to it as their business plan (Senior Manager).

The director of housing explained that for him to be able to manage an efficient and effective delivery of service, he needs clear reporting structures (i.e. rules, routines). A senior manager explained the housing director's situated rationality for introducing the BSC:

He would find it very hard to work in a place where he is not clear about things. He likes clear structures; he would hate to go into a meeting if he was not clear about something. He just has to have the facts, perhaps that is the engineering background in him. He likes to have things simple and straightforward in as far as he can. Some people would think the business plan (BSC) could be simplified further but for him they are happy with this process, it is as simple as it can be.

Thus, the new procedures made "life more predictable and thereby reduce ambiguity and anxiety" (Schein, 2017, p. 198). The director's newly developed business plan (Figure 3) listed the organisation's strategy for housing. It displayed the four typical BSC perspectives customer, internal process, learning and growth and financial. These were drawn upon by the director to outline housing's strategic objectives. The director believed that by clearly outlining housing's strategic objectives to his staff, its mission of "improving the quality of life of the people of [city] by enhancing the physical, social, cultural and economic environment in a sustainable and socially inclusive manner" would be achieved (Figure 3). The business plan helped the director manage his staff by clearly communicating to them what they should be striving toward:

I suppose the main thing about people is that they don't know what their big performance indicator is, what are we existing for? What do we get up in the morning for? The business plan

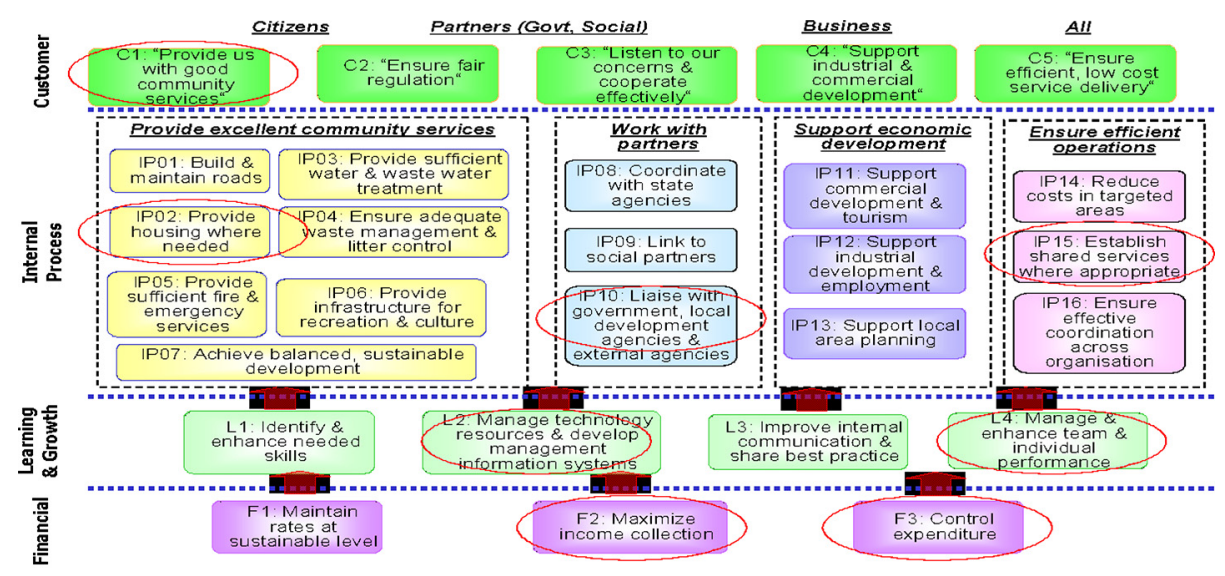

Note: Circled items detailed in Table 2

Source: Internal document 
sets out key performance indicators (KPI) for staff. The overall KPI for housing is the waiting list and how many people are on the waiting list (Senior Manager).

Table 2 shows the key strategic housing objectives determined by the housing director in the first year of using the BSC. The customer perspective (items C1-C5 in Figure 3 and $\mathrm{C} 1$ in Table 2) outlined how Irish Authority wished to provide its communities with the best housing service it could provide. The internal process perspective showed Irish Authority's desire to provide necessary housing, its intention to work closely with other government and external agencies who impact this process (IP items in Figure 3 and Table 2). Irish Authority also explored if shared services could be incorporated to enhance service-delivery of housing. For the learning and growth perspective, Irish Authority aimed to ensure its management information systems were up to date and that they had the required technologies to provide the best housing service possible (L items in Figure 3 and Table 2). They also wanted to implement an effective staff performance management system. Finally, for the financial perspective, Irish Authority aimed to maximise income and control expenditures ( $\mathrm{F}$ items in Figure 3 and Table 2). Each of the objectives in Figure 3 and Table 2 had performance measures and targets assigned, examples are the total number of dwellings in local authority stock and the percentage of housing rent arrears that are less than 4 weeks old. Staff held responsible for attaining each of the objectives were named on the business plan, they could see how they were being measured and whether they were on target or not reflective of the clarity of performance measures mentioned by Tessier (2014, p. 152). Thus, the management control information from the business plan facilitated

E. Strategic Objectives

C1: Provide us with good community services

We will assure that our communities have the best services we can affordably provide

IP02: Provide housing where needed

We will work to ensure that necessary housing is provided to support a comfortable lifestyle and the continued development of Irish Authority

IP10: Liaise with government, local development agencies and external agencies

We will assure effective liaison between our plans and activities and the plans and activities of other government, local development and external agencies whose activities impact Irish Authority

IP15: Establish shared services where appropriate

We will identify areas where a shared service approach can be implemented with improved service-delivery

L2: Manage technology resources and develop management information systems

We will ensure that we manage the technology resources available to us and that we have the management information systems we need, and that these systems work together in an integrated and effective fashion.

\section{L4: Manage and enhance team and individual performance}

We will implement an effective performance management system that will allow us to measure performance and to enhance the performance of each individual and team in the organisation

F2: Maximize income collection

We will continue to collect income for services provided, where appropriate, while identifying additional areas where fees would be appropriate and ensure that fees fully reflect the cost of services

F3: Control expenditure

We will continue to control all expenditure and will work to provide the required levels of services

Table 2

Irish Authority's housing department strategic objectives

\section{Management control change}

93

(2) 
QRAM

19,1

94 the director of housing to alleviate any ambiguities for staff by clarifying their roles, responsibilities and targets, which is akin to Hiebl (2018) who argues that management accounting information can be a political resource to aid change agents in organisational reforms. The business plan did transform management controls in housing and its targets were reviewed every six months. Having this performance management information allowed the managers to see where there were backlogs in their business units.

\section{Discussion}

As revealed, at Irish Authority, traditionally housing services were delivered independently through each of its units I, II and III, and each unit carried out its housing operations and service-delivery in a somewhat different manner. Having the housing service structured as three independent units with three directors of services, resulted in variations in service deliveries and management control practices leading to inefficiencies. As revealed earlier, when an economic recession hit and central government austerity measures kicked in, a change process began. The result of the change process was improved management controls (budgets being enforced and the introduction of a BSC), which delivered improved accountability. We now discuss the process in terms of the extended framework of terBogt and Scapens (2019), highlighting the role and leadership of key actors and their situated rationalities.

The economic crisis which hit the Irish economy was an initial catalyst for change. This external condition - broader institution as per terBogt and Scapens (2019) played "an important enabling role" (Battilana et al., 2009, p. 75), and such a broader institutional effect is captured in their framework. This broader institutional effect can be summarised as the need to operate in an austerity driven environment. This external factor contrasted with the incumbent institutionalised way of operating within the housing department, which was in effect limited controls on spending of available funds. Thus, arguably an institutional contradiction arose (Seo and Creed, 2002), and change was possible. If we follow terBogt and Scapens (2019) as per Figure 1 (right), this external broader institution of austerity practices [7] would interact with internal institutions and situated rationalities within the organisation. While this is true in some cases, it is not the full picture based on the story outlined earlier for Irish Authority. The situated rationality to complete the type of reform required at Irish Authority to cope with austerity did not exist. Earlier in Table 1, we highlighted the description of situated rationality as given by terBogt and Scapens (2019, pp. 1810-1811), namely, "the particular forms of rationality which are applied by individuals or groups of individuals in specific situations". In the context of Irish Authority, this poses two issues. First, the specific situation of austerity was arguably new and unforeseen, and thus what rationalities could be drawn on, may not have been clear to organisational actors. Second, if the rationalities did not exist within internal institutions, then terBogt and Scapens (2019) suggest broader institutions would be drawn upon (Figure 1), implying action and roles of actors. However, what is arguably explicitly missing from terBogt and Scapens (2019) is the importance of key individual actors in bringing about a new situated rationality in a case like Irish Authority. As hinted at in the previous section, the leadership of the $\mathrm{CE}$ was also relevant and in this paper this is considered analytically within the importance of key individuals.

The empirical data from Irish Authority highlights that the CE brought a particular situated rationality to the organisation, through his finance training and leadership - which we will term experience rationality. For example, the CE's past experiences saw him challenge existing ways of managing and delivering housing services (Schoemaker $e$ t al., 2013). Existing and past budget figures which were not clear were questioned 
(i.e. interpretation) (Schoemaker et al., 2013). As a second example, due to the contrasting answers received, it was evident to the $\mathrm{CE}$ that the housing service was complex, and it needed to be simplified (Bryant and Sharer, 2021). The CE needed answers to "where are we going and how are we getting there" (Bryant and Sharer, 2021). This questioning afforded the CE the opportunity to create a compelling narrative for change and achieve support from senior management as they could see transformation was needed (Bryant and Sharer, 2021). As a third example, the CE's ability to lead in a time of crisis was also discernible and followers were gained. The CE selected directors who agreed with the vision for reform as Management control change they would instil a culture of performance management. The CE also knew reform takes time and persistence, and the type of language used is important to retain followers.

He was able to apply this experience rationality to the new occurrence of austerity and knowledge that the housing department needed reform. By first commissioning the SSR on housing, the CE de-legitimised the existing housing structures and strove to achieve improved service-delivery and management control (Oliver, 1992). As highlighted earlier, one management control technique used to manage the new structure was budgeting. Although the fundamentals of budgetary control, which the CE and director of housing enforced within the housing department, may have been "normal" and "rational" in a typical organisation and in the CE's experience rationality, this was not the case at Irish Authority. However, the combined effect of the external austerity forces and the CE's experience rationality - which was new to Irish Authority as the CE and his leadership style was new acted as a stimulus to change existing budget practices, i.e. enforce them. The more normal and typical budget practices implemented by the $\mathrm{CE}$ can be equated to a generalised practice as per terBogt and Scapens (2019, p. 1811) - budgeting is a "coherent and concrete structure", which the CE drew upon to bring about new rules (and eventually routines) in the housing department. However, looking at Figure 1, there is no linkage in terBogt and Scapens (2019) of the three elements of generalised practice, situated rationalities and rules. In the case of budgeting at Irish Authority, for the CE to implement or use the generalised practice of budgetary control - that is, to enforce budget control rules - it was necessary to first adapt the form of rationality applied by individuals/groups within housing. terBogt and Scapens (2019, p. 1811) do note that "specific individuals [...] have power to impose rules on the other members of the organisation, [and] may draw on their situated rationality when imposing such rules". While this may be the case in some organisations and contexts, it presupposes - at least in the visual depiction of terBogt and Scapens (2019) - that situated rationalities are influenced by broader and internal institutions, and not by generalised practices. Thus, if we were to depict the implementation of budgeting at Irish Authority in a visual way following terBogt and Scapens (2019), a line from generalised practices (the generally accepted concepts of budgeting) to situated rationalities (the $\mathrm{CE}$ applying his experience rationality to the situation at hand) would be required.

As revealed earlier, a BSC - or business plan as it was termed internally - was introduced by the director of housing. To increase the chance of change within the housing department, the CE appointed a director of housing who believed in the reform. The CE's formal "right to make decisions" (Battilana et al., 2009, p. 84) and situated rationality (terBogt and Scapens, 2019) are evident here. The CE noted that the new housing director was the "best person to head it up as he had all the thought processes" - in other words, they shared a similar experience rationality. The new housing director, when drawing up the BSC (see Figure 3 and Table 2), drew from his educational background, his past and present local authority service experience as well as his ability to imagine alternative service management possibilities (Battilana and D'Aunno, 2009). He helped drive housing department reform via the BSC. As can be seen in Figure 3, the BSC (or business plan) used 
QRAM 19,1 terms from the standard Balanced Scorecard presented by Kaplan and Norton in the 1990s (Kaplan and Norton, 1996). This BSC was introduced by the director of housing himself as a tool to assist change, there was no imperative from inside or outside Irish Authority to do so. Thus, he drew on a new generalised practice (i.e. Kaplan and Norton's (1996) Balanced Scorecard) in his efforts to communicate clearly with staff and "to dismantle old taken-forgranted assumptions" (Burns and Baldvinsdottir, 2005, p. 735). In the terminology of terBogt and Scapens (2019) this, like the budgeting described above, again was an effort to change the situated rationality of the housing department by drawing on generalised practice. Again, we could not ascertain a link between the BSC and existing institutions at Irish Authority - see the earlier quote re the "lingo" (or language of a typical BSC) - as such a tool had never been used. Nor were any external broader institutions forcing or influencing Irish Authority to adopt a BSC as a management control tool. Thus, per terBogt and Scapens' (2019) framework, a generalised practice is the most suited term to apply to the BSC. Again, like the budgetary control example, the empirical data suggests the situated rationality of how to run and control the housing department needed to change before any new "rule" could be introduced. The BSC did transpose to a rule and became routinised as it was repeatedly used in the housing department. Again, if we were to depict the implementation of the BSC at Irish Authority in a visual way following terBogt and Scapens (2019), a line from generalised practices (the generally accepted practice of a BSC) to situated rationalities (the housing director and the $\mathrm{CE}$ applying experience rationality to the situation at hand) would be required. It is also worth noting that Irish Authority were questioned by other local authorities as to how they managed to make changes. The BSC and other elements of the process of change were communicated by the $\mathrm{CE}$ and housing director as key tools for change. Thus, changes at Irish Authority had potential to influence broader institutions as described by terBogt and Scapens (2019).

A further point on the housing department is worthy of mention. By its nature, the housing department was/is about people - and people in difficulty. At Irish Authority housing staff were viewed as being good at dealing with housing issues. They considered housing and social problems from their heart, and financial concerns were not priority - see the earlier comments on budget spending. This is an example of organisational fragmentation at Irish Authority where different job levels within the housing department appeared to have different situated rationalities. To overcome this fragmentation, power over resources was exercised by senior managers to embed structures and controls (i.e. budgeting and BSC) at Irish Authority. As the housing department structure and management control rules were changed and staff had to follow the new rules, subtle and gradual erosion occurred in the existing situated rationalities, which subsequently fed into new settled ways of thinking and acting (Burns and Scapens, 2000; terBogt and Scapens, 2019). The external environmental jolt (austerity) enhanced acceptance of these new housing rules. The director of housing also explained how the external environment created the urgency for reforms in housing but how that sense of urgency also had to be maintained during housing's new structure implementation. This again reflects the importance of key actors (the $\mathrm{CE}$ and director of housing) and their leadership and experience in bringing about change to the existing situated rationalities. It also suggests that the depiction of situated rationalities as a single homogenous "entity" within the framework of terBogt and Scapens (2019) is less reflective of the reality in organisations. While the housing department at Irish Authority may have had what could be conceived of as two situated rationalities (one from a social view, one from a financial view), it is not uncommon for organisation units/departments to have such competing logics. terBogt and Scapens (2019) do address this, as highlighted in Table 1, and do speak of a multiplicity of institutions which may affect situated rationalities, and to situated 
rationalities of groups. However, the empirical evidence from the housing department suggests that situated rationalities need to be considered in more fine-grained detail in empirical studies.

\section{Concluding comments}

In concluding this paper, we argue the empirical data from Irish Authority points to two issues on situated rationalities as conceived by terBogt and Scapens (2019). First, the nature of situated rationalities as depicted by them does not seem to consider, in sufficient detail, that key actors who may be involved in a change process may have their own situated rationalities (experience rationalities) which compete with existing organisational rationalities. Put another way, terBogt and Scapens (2019, p.1812) tend to focus more on the "situated rationalities of the various groups within the organisation" (emphasis added). It is also quite likely in empirical settings that competing situated rationalities exist within the same time and space, with more than one form of rationality existing. Second, terBogt and Scapens (2019) seem to have not fully depicted in their framework links between generalised practices and situated rationalities as suggested by the empirical data here. Reflecting these two issues into our research question, we can tentatively suggest that the role of situated rationalities of key individual actors (or experience rationality) in processes of management control change is an important one. Such experience rationalities may be a key element in successful change in complex settings of management control change.

To finish, the original Burns and Scapens' (2000) framework and that of terBogt and Scapens (2019) were always intended as foundations for further research. As the younger of the two, terBogt and Scapens (2019) has naturally received less attention. While this paper does present some insights on situated rationalities and their links to generalised practices, it is supportive of the general nature of the framework given by terBogt and Scapens (2019). More studies are required to enlighten their work, as here we are limited to data from a single and possibly somewhat unique (albeit interesting) context. Having said that, a focus on key actors and their experience rationalities in the processes of management control change is likely to yield fruitful insights.

\section{Notes}

1. Situated rationalities in this paper are defined as "the taken-for-granted ways of thinking which actors adopt when taking actions in a specific situation (ter Bogt and Scapens, 2019, p. 1804).

2. For anonymity reasons, this is not the organisation's real name.

3. This refers to laws requiring local authorities to seek permission for building projects they undertake.

4. The DD was a support department set up in Irish Authority by the CE to progress change and to look at the whole area of performance management.

5. The new director's management report will be examined later.

6. These plans were not the "business plans" referred to here and later in Figure 3.

7. It is appropriate to deem austerity as an institutionalised practice as it was repeated across Irish central and local government and had been embodied in emergency legislation.

\section{References}

Agle, B.R., Nagarajan, N.J., Sonnenfeld, J.A. and Srinivasan, D. (2006), "Does C.E.O. charisma matter? An empirical analysis of the relationships among organizational performance, environmental 
QRAM 19,1

uncertainty, and top management team perceptions of CEO charisma", Academy of Management Journal, Vol. 49 No. 1, pp. 161-174.

Ahrens, T. and Chapman, C.S. (2007), "Management accounting as practice", Accounting, Organizations and Society, Vol. 32 Nos 1/2, pp. 1-27.

Baños Sánchez-Matamoros, J., Araujo, P., P. and Alvarez-Dardet Espejo, C. (2014), "Management accounting change and agency in embedded situations", Spanish Journal of Finance and Accounting/Revista Española de Financiación y Contabilidad, Vol. 43 No. 3, pp. 241-265.

Bastardoz, N. and Van Vugt, M. (2019), "The nature of followership: evolutionary analysis and review", The Leadership Quarterly, Vol. 30 No. 1, pp. 81-95.

Battilana, J. (2006), "Agency and institutions: the enabling role of individuals' social position", Organization, Vol. 13 No. 5, pp. 653-676.

Battilana, J. and D'Aunno, T. (2009), "Institutional work and the paradox of embedded agency", Lawrence, T.B., Suddaby, R. and Leca, B. (Eds), Institutional Work: Actors and Agency in Institutional Studies of Organizations, Cambridge University Press, Cambridge, New York, NY, pp. 31-58.

Battilana, J., Leca, B. and Boxenbaum, E. (2009), "How actors change institutions: towards a theory of institutional entrepreneurship", Academy of Management Annals, Vol. 3 No. 1, pp. 65-107.

Bertz, J. and Quinn, M. (2014), "Interpreting management accounting rules: an initial study of public bodies", Journal of Management Control, Vol. 24 No. 4, pp. 319-342.

Boxenbaum, E. and Battilana, J. (2005), "Importation as innovation: transposing managerial practices across fields", Strategic Organization, Vol. 3 No. 4, pp. 355-383.

Bryant, A. and Sharer, K. (2021), The CEO Test: Master the Challenges That Make or Break All Leaders, Harvard Business Review Press, Boston.

Bryman, A. and Bell, E. (2015), Business Research Methods, Oxford University Press, Oxford.

Burchell, S., Clubb, C., Hopwood, A. and Hughes, J. (1980), "The roles of accounting in organisations and society", Accounting, Organizations and Society, Vol. 5 No. 1, pp. 5-27.

Burns, J. (2000), "The dynamics of accounting change inter-play between new practices, routines, institutions, power and politics", Accounting, Auditing and Accountability Journal, Vol. 13 No. 5, pp. 566-596.

Burns, J. and Baldvinsdottir, G. (2005), "An institutional perspective of accountants' new roles - the interplay of contradictions and praxis", European Accounting Review, Vol. 14 No. 4, pp. 725-757.

Burns, J. and Scapens, R.W. (2000), “Conceptualizing management accounting change: an institutional framework", Management Accounting Research, Vol. 11 No. 1, pp. 3-25.

Burns, J., Ezzamel, M. and Scapens, R.W. (2003), Challenge of Management Accounting Change, Elsevier, London.

Corley, K.G. and Gioia, D.A. (2011), "Building theory about theory building: what constitutes a theoretical contribution?”, Academy of Management Review, Vol. 36 No. 1, pp. 12-32.

Darling, J.R., Heller, V.L. and Wilson, I.I.I., B.J. (2012), “The key to effective organizational development in times of socioeconomic stress, a case focusing on leadership responses to communication challenges", European Business Review, Vol. 24 No. 3, pp. 216-235.

Dillard, J.F., Rigsby, J.T. and Goodman, C. (2004), "The making and remaking of organization context: duality and the institutionalization process", Accounting, Auditing and Accountability Journal, Vol. 17 No. 4, pp. 506-542.

Eisenhardt, K.M. (1989), "Building theories from case study research", The Academy of Management Review, Vol. 14 No. 4, pp. 532-550.

Englund, H. and Gerdin, J. (2008), "Structuration theory and mediating concepts: pitfalls and implications for management accounting research", Critical Perspectives on Accounting, Vol. 19 No. 8, pp. 1122-1134.

Englund, H. and Gerdin, J. (2018), "Management accounting and the paradox of embedded agency: a framework for analyzing sources of structural change", Management Accounting Research, Vol. 38, pp. 1-11. 
Englund, H., Gerdin, J. and Burns, J. (2020), "A structuration theory perspective on the interplay between strategy and accounting: unpacking social continuity and transformation", Critical Perspectives on Accounting, Vol. 73, pp. 1-14.

Garud, R., Hardy, C. and Maguire, S. (2007), "Institutional entrepreneurship as embedded agency: an introduction to the special issue", Organization Studies, Vol. 28 No. 7, pp. 957-969.

Hiebl, M.R.W. (2018), "Management accounting as a political resource for enabling embedded agency", Management Accounting Research, Vol. 38 No. 1, pp. 22-38.

Jørgensen, B. and Messner, M. (2010), "Accounting and strategising: a case study from new product development”, Accounting, Organizations and Society, Vol. 35 No. 2, pp. 184-204.

Kaplan, R.S. and Norton, D.P. (1996), "Using the balanced scorecard as a strategic management system”, Harvard Business Review, Vol. 1, pp. 75-85.

Leavy, B. (2021), "Bryant and sharer: seven challenges most likely to make-or-break leaders", Strategy and Leadership, Vol. 49 No. 2, pp. 22-28.

Lukka, K. (2007), "Management accounting change and stability: loosely coupled rules and routines in action”, Management Accounting Research, Vol. 18 No. 1, pp. 76-101.

McDermott, A., Kidney, R. and Flood, P. (2010), "Understanding leader development: learning from leaders", Leadership and Organization Development Journal, Vol. 32 No. 4, pp. 358-378.

McMullen, J.S., Wood, M.S. and Kier, A.S. (2016), “An embedded agency approach to entrepreneurship public policy: managerial position and politics in new venture location decisions", Academy of Management Perspectives, Vol. 30 No. 3, pp. 222-246.

Mason, J. and Dale, A. (2011), Understanding Social Research: Thinking Creatively about Method, Sage, London.

Matthews, S.H., Kelemen, T.K. and Bolino, M.C. (2021), "How follower traits and cultural values influence the effects of leadership", The Leadership Quarterly, Vol. 32 No. 1, pp. 1-14.

Mazzei, A. (2014), "Internal communication for employee enablement: strategies in American and Italian companies", Corporate Communications: An International Journal, Vol. 19 No. 1, pp. 82-95.

Miles, M.B. and Huberman, A.M. (1994), Qualitative Data Analysis: An Expanded Sourcebook, Sage. CA.

Nor-Aziah, A.K. and Scapens, R.W. (2007), "Corporatisation and accounting change. The role of accounting and accountants in a Malaysian public utility", Management Accounting Research, Vol. 18 No. 2, pp. 209-247.

Oliver, C. (1992), "The antecedents of deinstitutionalization”, Organization Studies, Vol. 13 No. 4, pp. 563-588.

Oliveira, J. and Quinn, M. (2015), "Interactions of rules and routines: re-thinking rules", Journal of Accounting and Organizational Change, Vol. 11 No. 4, pp. 503-526.

Quinn, M. (2011), "Routines in management accounting research: further exploration", Journal of Accounting and Organizational Change, Vol. 7 No. 4, pp. 337-357.

Quinn, M. (2014), "Stability and change in management accounting over time - a century or so of evidence from Guinness", Management Accounting Research, Vol. 25 No. 1, pp. 76-92.

Quinn, M. and Hiebl, M.R.W. (2018), "Management accounting routines: a framework on their foundations", Qualitative Research in Accounting and Management, Vol. 15 No. 4, pp. 535-562.

Saunders, M., Lewis, P. and Thornhill, A. (2015), Research Methods for Business Students, 7 ed., Pearson Education London.

Scapens, R.W. (1994), "Never mind the gap: towards an institutional perspective on management accounting practice", Management Accounting Research, Vol. 5 Nos 3/4, pp. 301-321.

Schein, E.H. (2017), Organizational Culture and Leadership, Wiley, NJ.

Schoemaker, P.J.H., Krupp, S. and Harland, S. (2013), "Strategic leadership: the essential skills", Harvard Business Review, Vol. 1, pp. 1-5. 
QRAM 19,1

Seo, M. and Creed, W.E.D. (2002), "Institutional contradictions, praxis, and institutional change: a dialectical perspective", The Academy of Management Review, Vol. 27 No. 2, pp. 222-247.

Shamir, B. (1991), "Meaning, self and motivation in organizations", Organization Studies, Vol. 12 No. 3, pp. 405-424.

Siti-Nabiha, A.K. and Scapens, R.W. (2005), "Stability and change: an institutionalist study of management accounting change", Accounting, Auditing and Accountability Journal, Vol. 18 No. 1, pp. 44-73.

Sturm, R.E., Hertz, H. and Antonakis, J. (2021), "The science of leader power", The Leadership Quarterly, Vol. 32 No. 4, pp. 1-7.

terBogt, H.J. and Scapens, R.W. (2019), "Institutions, situated rationality and agency in management accounting", Accounting, Auditing and Accountability Journal, Vol. 32 No. 6, pp. 1801-1825.

Tessier, S. (2014), "Managing management controls", Otley, D. and Soin, K. (Eds), Management Control and Uncertainty, Palgrave Macmillan, New York, NY pp. 149-161.

Thornton, P.H., Ocasio, W. and Lounsbury, M. (2012), The Institutional Logics Perspective, Oxford University Press, Oxford.

van der Steen, M. (2011), "The emergence and change of management accounting routines", Accounting, Auditing and Accountability Journal, Vol. 24 No. 4, pp. 502-547.

Webb, E.J., Campbell, D.T., Schwartrz, R.D. and Sechrest, L. (1966), Unobtrusive Measures: Nonreactive Measures in the Social Sciences, Rand McNally, Chicago.

Yazdifar, H. (2013), Management Accounting Systems the Dynamics of Management Accounting Systems Implementation in Complex and Multi-National Organizations, Lambert Academic Publishing, Lambert.

Corresponding author

Julie Bertz can be contacted at: julie.bertz@dcu.ie

For instructions on how to order reprints of this article, please visit our website: 